Viruses 2011, 3, 1959-1985; doi:10.3390/v3101959

\title{
viruses
}

ISSN 1999-4915

www.mdpi.com/journal/viruses

Review

\section{The Molecular Biology of Frog Virus 3 and other Iridoviruses Infecting Cold-Blooded Vertebrates}

\section{Gregory Chinchar ${ }^{1, *}$, Kwang H. Yu ${ }^{1}$ and James K. Jancovich ${ }^{2}$}

1 Department of Microbiology, University of Mississippi Medical Center, 2500 N. State Street, Jackson, MS 39216, USA

2 Department of Biology, California State University - San Marcos, 333 South Twin Oaks Valley Road, San Marcos, CA 92096, USA

* Author to whom correspondence should be addressed; E-Mail: vchinchar@umc.edu; Tel.: +1-601-984-1743; Fax: +1-601-984-1708.

Received: 30 August 2011; in revised form: 27 September 2011 / Accepted: 27 September 2011/ Published: 20 October 2011

\begin{abstract}
Frog virus 3 (FV3) is the best characterized member of the family Iridoviridae. FV3 study has provided insights into the replication of other family members, and has served as a model of viral transcription, genome replication, and virus-mediated host-shutoff. Although the broad outlines of FV3 replication have been elucidated, the precise roles of most viral proteins remain unknown. Current studies using knock down (KD) mediated by antisense morpholino oligonucleotides (asMO) and small, interfering RNAs (siRNA), knock out (KO) following replacement of the targeted gene with a selectable marker by homologous recombination, ectopic viral gene expression, and recombinant viral proteins have enabled researchers to systematically ascertain replicativeand virulence-related gene functions. In addition, the application of molecular tools to ecological studies is providing novel ways for field biologists to identify potential pathogens, quantify infections, and trace the evolution of ecologically important viral species. In this review, we summarize current studies using not only FV3, but also other iridoviruses infecting ectotherms. As described below, general principles ascertained using FV3 served as a model for the family, and studies utilizing other ranaviruses and megalocytiviruses have confirmed and extended our understanding of iridovirus replication. Collectively, these and future efforts will elucidate molecular events in viral
\end{abstract}


replication, intrinsic and extrinsic factors that contribute to disease outbreaks, and the role of the host immune system in protection from disease.

Keywords: ranavirus; Iridoviridae; virus replication; viral gene function; ectothermic vertebrates; antisense morpholino oligonucleotides; knock out mutants

\section{Taxonomy}

Frog virus 3 (FV3) is the type species of the genus Ranavirus (family Iridoviridae) [1-3]. The genus Ranavirus is one of five genera within the family: members of the Ranavirus, Megalocytivirus, and Lymphocystivirus genera infect cold-blooded vertebrates (amphibians, reptiles and bony fish, i.e., superclass Osteichthyes), whereas members of the remaining two genera (Iridovirus and Chloriridovirus) infect invertebrates, e.g., insects and crustaceans. The family Iridoviridae is phylogenetically linked to several other families of nuclear, cytoplasmic, large, DNA-containing viruses (NCLDV) such as Phycodnaviridae, Poxviridae, Asfaviridae, Ascoviridae, and Mimiviridae [4-7]. Because one of the genus designations (Iridovirus) is a variation of the family name, viruses within the family are generically referred to as iridovirids.

Iridovirids are large dsDNA containing viruses whose virions display icosahedral symmetry [3]. Virions range in size from $120-200 \mathrm{~nm}$ in diameter, although viruses within the genus Lymphocystivirus may be as large as $300 \mathrm{~nm}$. Consistent with this range of particle sizes, genomes, depending upon the virus, vary from 105-212 kbp and encode between 92-211 putative proteins (Table 1). Genomes of those viruses infecting fish (Lymphocystis disease virus, LCDV; Singapore grouper iridovirus, SGIV; and Epizootic haematopoietic necrosis virus, EHNV; Infectious spleen and kidney necrosis virus, ISKNV) are larger than those infecting amphibians and reptiles (FV3, soft-shelled turtle iridovirus, STIV; and Ambystoma tigrinum virus, ATV), whereas those infecting invertebrates (Invertebrate iridovirus 3, IIV-3; IIV-6, and IIV-9) are larger still. Virus-infected cells display morphologically distinct viral assembly sites (VAS) within the cytoplasm and virions are readily observed within VAS, paracrystalline arrays, or budding from the plasma membrane. The unique appearance of infected cells is strong presumptive evidence of iridovirid infection although additional biochemical and histological studies are needed to determine the precise genus and species of the infecting virus. In addition to different host preferences (i.e., vertebrates vs. invertebrates), ranaviruses, megalocytiviruses, and lymphocystiviruses differ from the other two genera by their high level ( $\sim 25 \%)$ of cytosine methylation. Division of the family into two subfamilies (Chordiridovirinae and Invertiridovirinae) based on methylation status and host preference is currently being considered. However, the observation that some ranaviruses (SGIV) lack a virus-encoded DNA methyltransferase gene [8], and that some invertebrate iridoviruses appear to infect reptiles [9,10], suggests caution in this regard. 
Table 1: Sizes and coding potentials of iridovirid genomes.

\begin{tabular}{|l|l|l|l|l|l|}
\hline Genus & Species $^{\mathbf{a}}$ & Size (bp) & No. ORFs & \% G+C & GenBank Accession Number \\
\hline & IIV-9 & 206,791 & 191 & 31 & GQ918152 \\
\hline & IIV-6 & 212,482 & 211 & 29 & AF303741 \\
\hline & & & & & \\
\hline Chloriridovirus & IIV-3 & 191,132 & 126 & 48 & DQ643392 \\
\hline & & & & & \\
\hline Lymphocystivirus & LCDV-1 & 102,653 & 108 & 29 & L63545 \\
\hline & LCDV-C & 186,250 & 178 & 27 & AY380826 \\
\hline & & & & & \\
\hline Ranavirus & TFV & 105,057 & 105 & 55 & AF389451 \\
\hline & ATV & 106,332 & 92 & 54 & AY150217 \\
\hline & FV3 & 105,903 & 97 & 55 & AY548484 \\
\hline & STIV & 105,890 & 103 & 55 & EU627010 \\
\hline & EHNV & 127,011 & 100 & 54 & FJ433873 \\
\hline & SGIV & 140,131 & 139 & 49 & AY521625 \\
\hline & GIV & 139,793 & 139 & 49 & AY666015 \\
\hline & & & & & \\
\hline Megalocytivirus & ISKNV & 111,362 & 117 & 55 & AF371960 \\
\hline & RBIV & 112,080 & 116 & 53 & AY532606 \\
\hline & RSIV & 112,414 & 93 & 53 & BD143114 \\
\hline & OSGIV & 112,636 & 116 & 54 & AY894343 \\
\hline & TRBIV & 110,104 & 115 & 55 & GO273492 \\
\hline & & & & & \\
\hline
\end{tabular}

${ }^{\text {a }}$ IIV-9, Invertebrate iridovirus type 9 (Wiseana iridovirus); IIV-6, Invertebrate iridovirus type 6 (Chilo iridovirus); IIV-3, Invertebrate iridovirus type 3 (mosquito choriridovirus); LCDV-1, Lymphocystis disease virus 1; LCDV-C, Lymphocystis disease virus - China; TFV, tiger frog virus; ATV, Ambystoma tigrinum virus; FV3, Frog virus 3; STIV, soft-shelled turtle iridovirus; EHNV, Epizootic haematopoietic necrosis virus; SGIV, Singapore grouper iridovirus; GIV, grouper iridovirus; ISKNV, Infectious spleen and kidney necrosis virus; RBIV, rock bream iridovirus; RSIV, red seabream iridovirus; OSGIV, orange spotted grouper iridovirus; TRBIV, turbot reddish body iridovirus. Viral names in italics indicate viral species recognized by the International Committee on Taxonomy of Viruses; those in standard type are either unrecognized species or isolates of recognized species; synonyms are indicated within parentheses.

${ }^{\mathrm{b}}$ Number of putative ORFs [11-14].

\section{Vital Statistics: Virion Structure and Genomic Organization}

\subsection{Virion Morphology and Composition}

Aside from differences in virion and genome sizes, the organization of virus particles within the family is generally similar. While transmission electron microscopy (TEM) has been conducted using FV3 and other iridovirids, detailed cryo-electron microscopic (CryoEM) analyses (discussed below) were performed with IIV-6 and provide the most detailed view of virion structure. Virions exist in two forms: non-enveloped particles $\sim 120-180 \mathrm{~nm}$ in diameter, and enveloped particles that acquire an envelope by budding from the plasma membrane. In addition to the external envelope, some iridovirids 
contain a fringe of fine fibers (fibrils) that extend outward from the capsid subunits $[15,16]$. Non-enveloped particles are composed of three distinct layers: an outer capsid composed of multiple copies of an $\sim 50 \mathrm{kDa}$ major capsid protein (MCP), an internal lipid membrane possibly derived from the endoplasmic reticulum (ER) or other cellular membranes, and an inner core containing the viral genome and associated virus-encoded proteins [16,17]. The MCP shows marked sequence conservation within all members of the family [18]. Sequence identity within the MCP gene allows primer-based PCR amplification of viral DNA and provides an easy way to determine whether a given virus is a member of the family and to which genera it belongs [19]. Although the MCP is the primary structural protein and comprises $40 \%$ of the total virion protein content, an additional 36 proteins have been identified following gel analysis of purified virions [3]. While many of these proteins likely represent virus-encoded catalytic proteins that play various roles in replication, three minor capsid proteins have been identified by CryoEM analysis of IIV-6 and designated as finger, zip, and anchor proteins [17]. Finger and zip proteins were suggested to stabilize the virus by acting as intercapsomer cross-links, whereas the anchor proteins appear to be transmembrane proteins that extend into the internal lipid membrane and provide further stabilization. In addition to these proteins, a fifth protein, a putative myristoylated protein (FV3 ORF 53R), has been suggested to interact with cellular membrane fragments and play a role in virion assembly [20].

\subsection{Genomic Organization}

As shown in Table 1, iridovirid genomes range in size from 105-212 kbp. Ranavirus genomes occupy the low end of this range and fall into three groups: the genomes of FV3, ATV, TFV, and STIV are 105-106 kbp, EHNV is $127 \mathrm{kbp}$, whereas SGIV and GIV, likely isolates of the same viral species, are $140 \mathrm{kbp}$ in size. Consistent with their sizes, ranaviruses contain between 92 and 139 close-packed, predominantly non-overlapping ORFs of 50 amino acids or greater [3,11-13]. Repetitive regions are common and may explain the high rate of recombination seen within these viruses. In addition, a small number of putative microRNAs of unknown function have been detected [21]. Amino acid conservation is marked among iridovirid genes, but gene order, even within members of the same genus, is not conserved suggesting that expression is likely determined by individual promoter elements closely associated with each gene. Moreover, although viral genes are expressed in an ordered temporal cascade (consisting of immediate early (IE), delayed early (DE), and late (L) genes) nucleotide sequences corresponding to IE, DE, and L promoters have not yet been identified. The observation that gene order is not conserved supports the view that genes can be reshuffled through recombination without adversely affecting expression. Microarray analysis suggests that FV3 contains $33 \mathrm{IE}, 22 \mathrm{DE}$, and $36 \mathrm{~L}$ genes [22]. Moreover, the classes assigned in that study were generally similar to those assigned to known SGIV genes in two earlier studies [23,24]. Although all ranaviruses contain a core set of 72 genes [11], unique genes are found within specific viral species. Genes held in common (e.g., viral DNA polymerase, MCP, the large and small subunits of the viral RNA transcriptase, etc.) are thought to be those required for replication in all cell types, whereas those unique to a given viral species may represent specific host adaptations that contribute to virulence, host range, and immune evasion. 


\section{Viral Replication Strategy}

Early studies of iridovirid replication were conducted almost exclusively using FV3, whereas recent studies have included additional ranaviruses such as ATV and SGIV and several megalocytivirus isolates that have been linked to massive die-offs in mariculture facilities in Japan and south-east Asia. Below we summarize events in FV3-infected cells and highlight recent work that has appeared since the last comprehensive reviews $[1,2,15,25]$.

\subsection{Virion Entry}

FV3 virions, and presumably virions of all other iridoviruses, exist in two forms: non-enveloped (i.e., naked) particles and enveloped virions. Although both forms are infectious, enveloped virions were shown to have higher specific infectivity [26,27]. With regard to entry, enveloped particles likely enter cells by receptor-mediated endocytosis in a $\mathrm{pH}$-dependent manner and require clathrin-coated pits, whereas naked particles enter by fusion at the plasma membrane [26,28]. Recently this model has been questioned by Guo and co-workers who argued that tiger frog virus (TFV), a ranavirus nearly identical to FV3, enters cells by an atypical, pH-dependent, caveola-mediated endocytic pathway [29]. Their conclusion was based on experiments using chlorpromazine and over-expression of a dominant-negative form of Esp15 that inhibited assembly of clathrin-coated pits, but did not affect entry. Consistent with a role for caveolae, endocytosis of TFV was dependent on membrane cholesterol and was blocked by caveolin-1 scaffolding domain protein. Given that FV3 and TFV are nearly identical in nucleotide sequence [30,31], it is surprising that their modes of entry are so different. Because the reported differences in entry mechanisms between FV3 and TFV may be due to infection of cells from different non-physiological hosts, e.g., rats and hamsters, resolution of this issue will require direct comparison of TFV and FV3 entry using the above approaches coupled with TEM.

\subsection{Early Events/Nuclear Phase}

Regardless of whether uncoating takes place at the plasma or nuclear membranes, the viral genome enters the nucleus. Unlike herpesviruses, iridovirid genomes are not infectious, indicating that virion-associated proteins are required to initiate viral gene transcription [32]. Accordingly, immediate-early (IE) and delayed early (DE) viral transcripts are synthesized in reactions mediated by putative virion-associated (for IE transcripts) and virus-encoded (for DE mRNA) transcriptional trans-activators and, at least for IE transcription, host RNA polymerase II [33-35]. Among the products of early transcription is a viral DNA polymerase which catalyzes the synthesis of unit-sized copies of the viral genome within the nucleus [36]. Additional IE and DE proteins include proteins that may play roles in blocking host immune responses such as a virus-encoded, CARD (caspase activation and recruitment domain) motif-containing protein (vCARD), $\beta$-hydroxysteroid dehydrogenase ( $\beta \mathrm{HSD}$ ), and a RNAse III-like protein, catalytic proteins involved in nucleic acid synthesis (Proliferating Cell Nuclear Antigen [PCNA], DNA methyltransferase [DMTase], the large and small subunits of the viral homolog of cellular RNA polymerase II [vPOL-II $\alpha$ and -II $\beta$ ], transcription factor IIS), catalytic proteins that may act to increase dTTP pool sizes and influence host range (deoxyuridine triphosphatase [dUTPase], deoxynucleotide kinase, the large and small subunits of ribonucleotide 
reductase), and proteins non-essential for replication in vitro, but needed for growth in vivo (the $18 \mathrm{~K}$ protein) [22].

\subsection{Late Events/Cytoplasmic Phase}

Following its synthesis, unit-sized viral DNA is transported into the cytoplasm where it is methylated by a virus-encoded DMTase and, following a second round of DNA synthesis, converted into large concatameric molecules that are thought to be the substrate from which viral genomes are derived [36-38]. Virion formation takes place in electron-lucent, morphologically-distinct VAS. VAS contain viral DNA and the structural and non-structural proteins that give rise to virions, but are devoid of ribosomes, mitochondria, and other cellular organelles [39,40]. Although little is known about the precise process of virion morphogenesis, by analogy to African swine fever virus and by study of various iridovirids, it appears that host membranes, perhaps derived from the ER, serve as a scaffold to which capsid and shell proteins bind [41,42]. As progressively larger amounts of viral proteins bind the membrane scaffold, crescent-shaped structures that resemble icosahedral vertices are formed. Ultimately both full and empty icosahedral virus-like particles are detected. However, it is unclear precisely how the genome is encapsidated. While packaging via a headful mechanism explains the circularly-permuted terminal redundancy detected within all iridovirids [43], it is not known whether nearly complete virions bind viral DNA and internalize it through a virion portal as seen in some viral systems [44-46], or whether developing crescents/icosahedrons engulf the viral genome as they assemble. Following their formation, virions remain within VAS, accumulate within cytoplasmic paracrystalline arrays, or bud from the plasma membrane. At late times after infection, virions are sometimes seen within the nucleus and elongated tubular structures can be detected in VAS, but these are likely artifacts that reflect breakdown of the nuclear membrane and the disruption of the assembly process due to the shortage of key structural proteins and the dysregulation of cellular and viral macromolecular synthesis. A transmission electron micrograph of an FV3-infected fathead minnow cell is shown in Figure 1A, and an enlargement of the VAS, displaying full and empty virions, is shown in Figure 1B.

The identities of virus-encoded proteins involved in virion assembly remain to be determined. Twelve complementation groups defective in the ability to synthesize infectious virions have been identified through study of temperature-sensitive $(t s)$ mutants (see below), but it is unclear whether the gene products encoded by these 12 complementation groups represent scaffold proteins that are required for virion assembly, but which are not incorporated into mature particles, authentic viral structural proteins, or virion-associated accessory proteins required for viral replication [47]. Aside from the MCP, only FV3 ORF 53R, which encodes a putative myristoylated membrane protein, has been linked to virion assembly. Knock down studies using either asMOs or artificial microRNAs $[20,48]$ demonstrated that 53R was required for virion assembly, whereas in vitro studies showed 53R was associated with virus factories and the virion membrane [49]. By analogy to ASFV, 53R may play a role in recruiting ER-derived membranes into virus factories where they serve as precursors of the inner viral lipid membrane and/or act as a scaffold protein. 
Figure 1. Ultrastructural analysis of FV3-infected FHM cells. (A) An FV3-infected cell displaying virions budding from the plasma membrane (long arrow) or present within a paracrystalline array (short arrow), a viral assembly site (star), and the nucleus (N) showing chromatin condensation; (B) an enlargement of a viral assembly site (star) showing both full and empty virions and possible assembly intermediates. The assembly site is surrounded by mitochondria (M) and membraneous structures, possibly elements of the endoplasmic reticulum (ER).
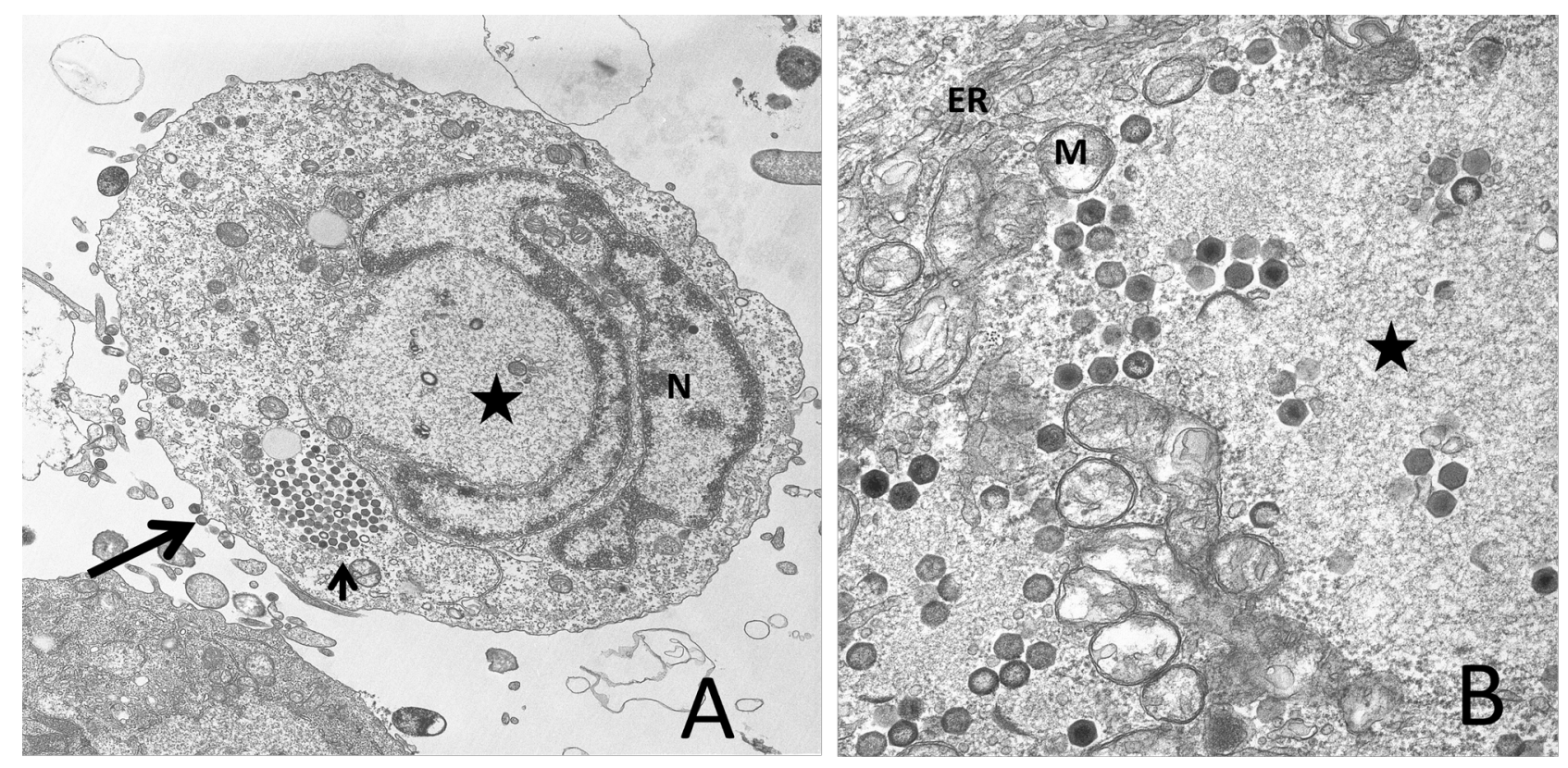

As with other nuclear and cytoplasmic, large DNA viruses (NCLDV) late viral gene expression is dependent upon full viral DNA synthesis, and is catalyzed by a virus-encoded or virus-modified transcriptase [47]. Temperature-sensitive mutants defective in viral DNA synthesis show markedly reduced levels of late gene expression as do cells treated with drugs (phosphonoacetic acid [PAA], cytosine arabinoside [araC]) that block DNA synthesis [50,51]. FV3 and other iridovirids encode homologs of the two largest subunits of RNA polymerase II and likely use these proteins, and perhaps others, to catalyze late viral gene expression [30]. Knock down of the expression of the largest subunit of the viral homolog of RNA polymerase II (i.e., vPOL-II $\alpha$ ) results in a marked reduction in the synthesis of late viral proteins and a corresponding reduction in virion formation and supports the notion that vPOL-II $\alpha$, and other viral proteins, are responsible for late viral gene expression [52]. Aside from the MCP, other late proteins tentatively involved in DNA packaging and virion assembly include ORF 1R, a putative packaging protein, and EVR1/ALR, a protein involved in the formation of disulfide bonds [53]. To illustrate the above, a schematic diagram of the viral replication cycle is shown in Figure 2. 
Figure 2. Life cycle of Frog virus 3 (FV3). The life cycle of FV3 is shown in schematic form. See text for details [54]. Used with permission.

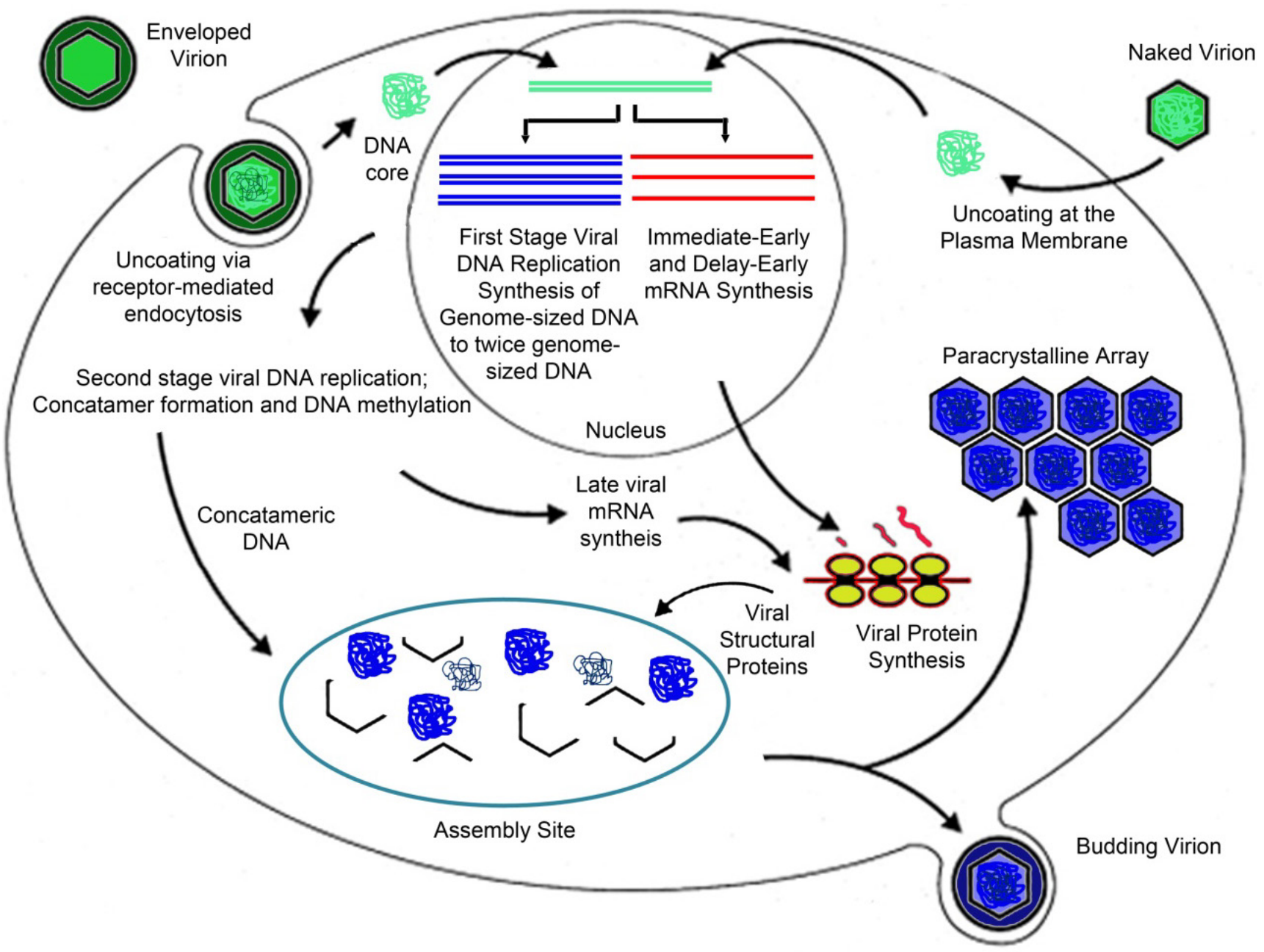

\subsection{Effect of Virus Infection on Host Functions}

As with other viruses, FV3 infection markedly inhibits host macromolecular synthesis and triggers apoptosis [55-58]. Both phenomena are mediated by heat- or UV-inactivated virus indicating that the inhibitory agent is a virion-associated protein [58,59]. Viral infection appears to trigger activation of PKR, a double-stranded RNA-activated protein kinase, which leads to the phosphorylation of the largest subunit of eukaryotic initiation factor 2 (eIF-2 $\alpha$ ) and the subsequent inhibition of protein synthesis [56]. Viral translation may be spared due to the synthesis of large amounts of highly efficient viral transcripts and the presence of a virus-encoded protein, e.g., a viral homolog of eIF-2 $\alpha$ (vIF-2 $\alpha$ ), that acts as a pseudosubstrate and prevents phosphorylation/inactivation of eIF-2 $\alpha$ [57,60-62]. Most ranaviruses, with the exception of FV3, contain a full-sized vIF-2 $\alpha$ gene [63,64]. However, because the absence of a full-sized vIF- $2 \alpha$ gene in FV3 does not adversely affect viral protein synthesis, other viral proteins may also play roles in maintaining viral protein synthesis in infected cells.

Aside from the aforementioned vIF- $2 \alpha$ protein, FV3 and other ranaviruses encode a number of putative immune evasion gene products including $\beta H S D$, vCARD, and an RNAse III-like protein. By analogy to a similar protein in vaccinia virus, $\beta$ HSD is thought to trigger glucocorticoid synthesis in infected animals and enhance virus replication by suppression of the overall immune response $[65,66]$. 
Likewise, vCARD may inhibit the induction of interferon and/or apoptosis. Induction of IFN and/or apoptosis follows interaction of RIG-I or MDA5, cellular proteins that bind dsRNA, with downstream effectors such as MAVS and ISP-1 [67-73]. Since RIG-I/MDA5 and MAVS/ISP-1 interactions are mediated by CARD motifs, it is possible that a viral CARD-containing protein might bind either one or both of these proteins and short-circuit the IFN induction pathway [74]. The RNAse III-like protein is found within all iridoviruses and has been postulated to block siRNA-mediated interference, or to play a role in the processing of viral mRNAs [75]. Alternatively, viral RNAse III could act like vaccinia virus E3L and bind and/or degrade dsRNA and block the activation of PKR, the induction of interferon, and the inhibition of protein synthesis [62].

As with vaccinia virus [76-78], iridoviruses that infect ectothermic animals encode a series of proteins whose function is to ensure an adequate supply of nucleotides for viral DNA synthesis. These enzymes include the two subunits of ribonucleotide reductase [79,80], thymidine kinase [30], thymidylate synthase, dUTPase [81], purine nucleoside phosphorylase (PNP), and a dihydrofolate reductase homolog $[12,82]$. Not all of these putative enzymes are found within each viral species, and it is postulated that specific enzymes might be needed in certain hosts. For example, PNP is found only within GIV and it has been suggested that because GIV's natural host, the grouper, might not be able to supply the purine nucleotides required for viral replication the virus encodes its own PNP [82].

\section{Viral Genomes and Evidence for Host Shifts}

Currently there are seven completely-sequenced ranavirus genomes ranging in size from 105-140 kbp (Table 1). Whole genome dot plot analyses show that there are three distinct genomic organizational profiles among ranaviruses that are based on the conservation of gene order [12]: FV3-like viruses (i.e. FV3, TFV and STIV), ATV-like viruses (i.e. ATV and EHNV) and GIV-like viruses (i.e. SGIV and GIV). Dot plot comparisons of viruses within each group show complete co-linearity. However, comparison of ATV-like ranaviruses with FV3-like ranaviruses detected two large inversions, whereas comparing either of these groups to GIV-like viruses revealed very little conservation of gene order $[11,83]$. In the latter case, gene order is so jumbled between FV3/ATV-like viruses and SGIV/GIV-like viruses that any trace of the 45 degree diagonal line, indicative of complete sequence alignment between genomes in dot plots, is lost. Interestingly, ranavirus genomic organization is markedly different from that of poxviruses. For example, all members of the subfamily Chordopoxvirinae share a conserved genomic core structure wherein gene order, with the single exception of avipoxviruses, is conserved [84]. However, despite the conservation of gene order, global sequence alignments show that sequence identity among members of the Chordopoxvirinae is only $27-29 \%$ [85,86]. Ranaviruses, on the other hand, share a much greater sequence identity ( $72-95 \%$ within the MCP) yet have three widely divergent genomic organizations. Moreover, as additional ranavirus genomes are sequenced, we may discover novel genomic morphotypes that will elucidate the evolutionary relatedness of ranaviruses.

Examination of complete ranavirus genomic sequences, including whole genome dot plot and phylogenetic analyses of ranavirus core genes, suggested that ranaviruses have undergone a number of evolutionarily-recent host shifts [12,87]. Phylogenetic analysis using the 26 core iridovirid genes identified by Eaton and her co-workers [11] support whole genome dot plot analysis and indicate that 
FV3-like viruses (FV3, TFV, STIV), ATV-like viruses (ATV and EHNV), and GIV-like viruses (SGIV and GIV) cluster on separate branches of the ranavirus tree (Figure 3). Collectively, these data suggest that for the greater part of their evolutionary history, ranaviruses were restricted to infecting fish. In addition, the shallow branch lengths of FV3-like and ATV-like viruses, which infect amphibians and fish, suggest that this group of viruses has recently, at least in evolutionary terms, radiated to infect a wide-range of poikilothermic vertebrates [12]. This hypothesis is supported by studies showing that ranaviruses are multi-host pathogens [88]. As additional ranaviruses are sequenced, particularly those isolates that infect multiple host species, a better understanding of ranavirus evolution, host shifts, and the molecular determinants of ranavirus host range and pathogenesis will be achieved.

Figure 3. Phylogenetic analysis of iridovirus genomes. A concatenated iridovirus phylogeny using 26 conserved open reading frames from completely sequenced members of the family Iridoviridae. The tree was created using Mega4 with the Neighbor-Joining method, bootstrap (500 replicates) and pairwise deletion options [89]. Members of the genus Ranavirus are highlighted in red.

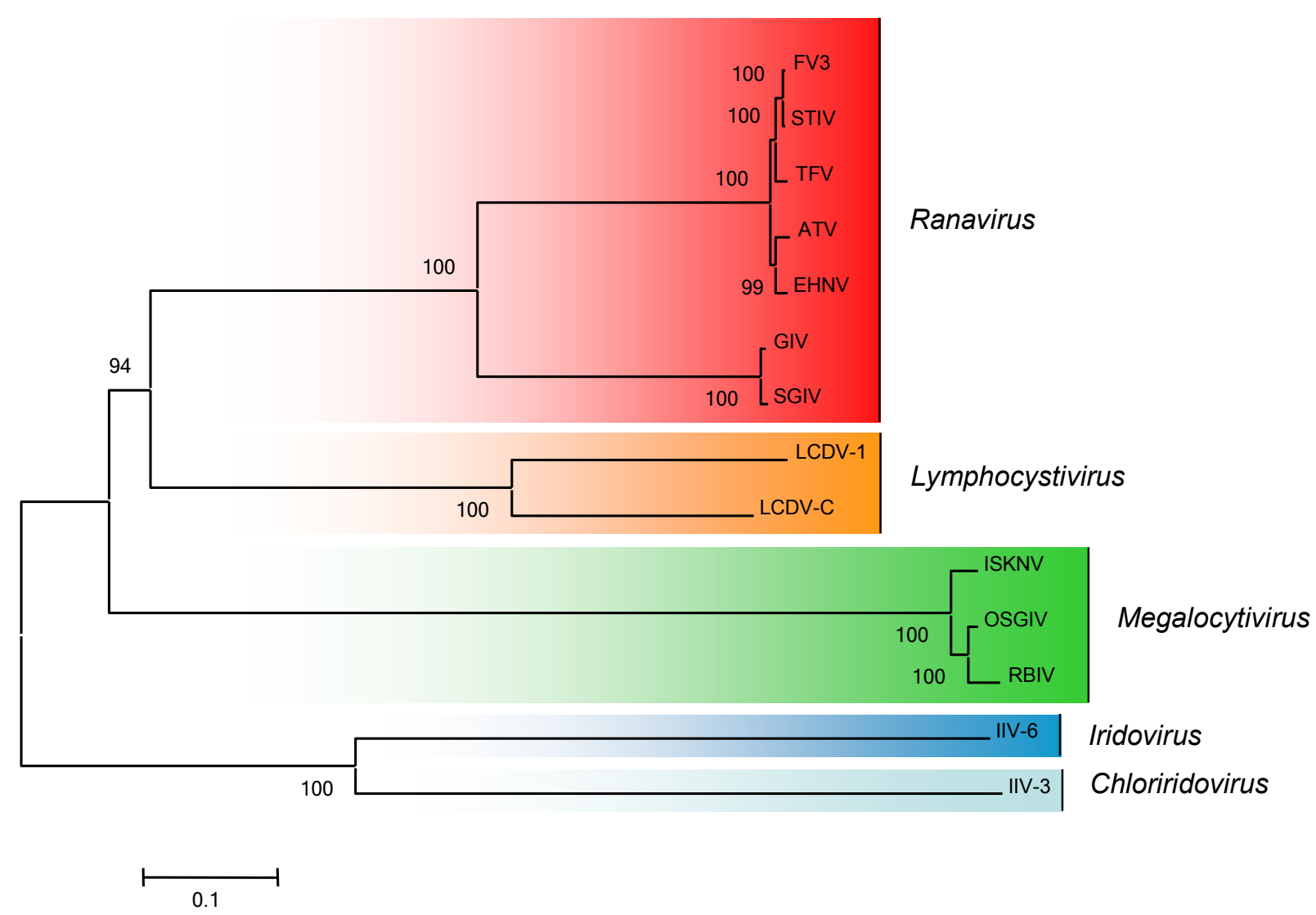

\section{Pathological and Immunological Aspects of RV Infection}

Pathological and immunological aspects of infection by FV3 and various iridovirids will be dealt with by Chen and Robert [90] and Miller et al. [91] in this special issue of Viruses. Thus, only a brief overview of this topic will be provided here. Although iridovirids, in contrast to the chytrid fungus Batrachochytrium dendrobatidis (Bd), have not been reported to drive species extinction, FV3-like 
viruses have caused deaths in several amphibian culture facilities and in nature, and megalocytiviruses have triggered wide-spread mortality in mariculture operations in south-east Asia [1,2,92-95]. Ranavirus infections range from inapparent to fulminant and involve a variety of tissues including the skin, kidney, liver, and intestine [96]. Using Xenopus laevis as a model host, Robert and his colleagues have shown that FV3 infection occurs in both larval and adult animals [96-102]. However, whereas infections of immunocompetent adult frogs are confined to the kidney and cleared within a few weeks, infection of tadpoles or immunocompromised adults results in widespread infection that spreads to multiple internal organs and often leads to death. Protection from FV3 infection appears to involve both humoral and cell-mediated immunity and both antiviral antibodies and cytotoxic $\mathrm{T}$ cells have been identified as protective. Vaccination may prove useful in protecting susceptible species and vaccines have been developed to protect commercially important fish from megalocytivirus infection [103,104]. Likewise, infection of bullfrog tadpoles (Rana catesbeiana) with less pathogenic FV3 protected them against death following infection with the more pathogenic Rana catesbeiana virus Z [63].

\section{Ecology of Iridovirus Infections}

As with the above section, the ecology of ranavirus infections will be more fully discussed by Miller and co-workers in their contribution to this issue [91]. Suffice it to say iridovirus infections have a marked effect on lower vertebrates. As Green and co-workers observed most mortality events seen among amphibians from 1996-2001 were attributable to iridovirus infections [105]. In addition, whereas lymphocystivirus and megalocytivirus infections have, to date, only been detected in fish species, ranavirus infections affect three classes of ectothermic vertebrates: bony fish, amphibians, and reptiles [2]. Results from experimental challenges as well as natural infections suggest that ranaviruses isolated from one species can not only infect different host species within the same genus, but also host species from different genera, orders, and classes. For example, amphibian ranaviruses such as Bohle iridovirus, FV3, and ATV infect a variety of fish and amphibian species, and at least one insect virus appears to also infect reptiles [9,10,88,106-109].

\section{Elucidation of Viral Gene Function}

\subsection{Early Studies: Temperature-Sensitive (ts) Mutants and Biochemical Studies}

Early studies with FV3 attempted to elucidate viral replicative events and the function of viral gene products using a variety of inhibitors, e.g., cycloheximide to confine viral gene expression to IE transcription, $\alpha$-amanitin to block host RNA polymerase II activity, phosphonacetic acid to block viral DNA synthesis, azacytidine to block the methylation of viral DNA, flurophenylalanine to block the expression of late viral proteins, elevated temperatures $\left(37{ }^{\circ} \mathrm{C}\right)$ to confine viral gene expression to early transcripts and proteins, etc. (reviewed in [110,111]). In addition, panels of $t s$ mutants were generated and subsequently characterized [47,112,113]. Ts mutants proved useful in confirming and identifying various aspects of the virus life cycle, e.g., the two-stages of viral DNA synthesis [114]. Ultimately, $28 \mathrm{ts}$ mutants were organized into 19 complementation groups comprising three classes [47]. Class I mutants (12 complementation groups) appeared to contain mutants with defects in virus 
assembly. These mutants synthesized early and late viral proteins and viral DNA, but did not generate infectious virions [47]. Recently, TEM analysis suggested that this class could be further sub-divided into at least two subclasses, those that failed to assemble icosahedral particles and those that formed ostensibly normal, but non-infectious, icosahedral particles at the non-permissive temperature [115]. The remaining complementation groups appeared to contain defects in proteins associated with viral transcription (Class II) and viral DNA synthesis (Class III). Consistent with an early study suggesting that only early viral proteins were required for assembly site formation [116], TEM analysis suggested that full viral DNA synthesis was not required for the formation of viral assembly sites as two $t s$ mutants that synthesized markedly reduced levels of viral DNA were able to form large VAS, that were devoid of viral DNA, most viral proteins, and viral particles [47,115]. However, although $t s$ mutants have contributed to our understanding of FV3 replication, it has not been possible to associate a given mutant phenotype with a specific viral ORF, and thus link a specific viral protein with its function. To address this issue, we have recently developed approaches that target individual viral genes and have used them to determine viral gene function by observing changes in phenotype.

\subsection{Knock Down of Viral Gene Expression Using asMOs}

To link specific viral proteins with their functions, viral gene expression was knocked down (KD) using antisense morpholino oligonucleotides (asMOs) and gene function was inferred by changes in phenotype. AsMOs are DNA-like macromolecules, optimally 25 nucleotides in length, whose backbone contains morpholine rings instead of deoxyribose rings and non-ionic, phosphorodiamidate bonds in place of phosphodiester links [117]. Moreover, because phosphorodiamidate bonds are resistant to degradation by cellular nucleases, asMOs are remarkably stable in cell culture [117]. Furthermore, in contrast to siRNAs that sometimes trigger off-targeting effects by activating pattern recognition receptors such as toll-like receptor 3 (TLR-3), asMOs are not recognized by cellular DNA receptors such as TLR-9 or AIM-2 and thus do not induce innate immune responses. asMOs bind complimentary sequences within the 5' non-translated region, or the region immediately surrounding the AUG initiation codon, of the targeted mRNA and are thought to block scanning of the $40 \mathrm{~S}$ ribosome by steric hindrance. In addition, asMOs also block gene expression by inhibiting splicing or preventing interaction of regulatory proteins with their specific target sequence [118]. Collectively asMOs have been used to block cellular and viral gene expression both in vitro and in vivo [119-121].

AsMOs have been used to ascertain the function of several FV3 genes including those encoding the MCP, vPol-II $\alpha$, an $18 \mathrm{kDa}$ immediate-early viral gene product $(18 \mathrm{~K})$, a putative myristoylated membrane protein (53R), and two IE proteins of unknown function: a $70 \mathrm{kDa}$ protein designated 32R, and $46 \mathrm{kDa}$ protein termed 46K [20,52,122,123]. In an initial proof-of-concept study, Sample et al. [52] showed that asMO treatment knocked down MCP expression by greater than $80 \%$ and resulted in a corresponding drop in the production of infectious virions without any collateral adverse effects on the expression of other viral gene products. Moreover, MCP knock down was accompanied by the appearance of atypical elements within VAS suggesting that in the absence of full MCP expression aberrant viral structures, perhaps representing altered products of virion assembly, were generated. In the same study, KD of vPOL-II $\alpha$ was shown to result in a marked reduction in the synthesis of late viral proteins. This result provided the first formal evidence that viral homologs of 
host RNA polymerase II played a role in the synthesis of late viral transcripts. Lastly, Sample and co-workers observed that KD of the $18 \mathrm{~K}$ IE protein had no observable effect on viral gene expression or replication in vitro suggesting that, at least in fathead minnow cells, $18 \mathrm{~K}$ was not required for the production of infectious virions. Subsequent $\mathrm{KD}$ studies of 53R, a putative virus-encoded myristoylated membrane protein, $32 \mathrm{R}$, and $46 \mathrm{~K}$ confirmed an essential role for each of these proteins in FV3 biogenesis [20,122]. KD of 53R resulted in the appearance of putative non-encapsidated viral DNA cores within VAS and supported the view that 53R plays a major role in capsid formation. KD of $32 \mathrm{R}$ and $46 \mathrm{~K}$, two IE proteins, did not affect the synthesis of other viral proteins, but resulted in a $>80 \%$ reduction in virion formation. TEM study showed that cells treated with asMOs targeting either $32 \mathrm{R}$ or $46 \mathrm{~K}$ formed viral assembly sites, but failed to form virions or recognizable assembly intermediates.

Studies targeting the virus-encoded RNAse III-like protein (ORF 80L), a putative NTPase (ORF 9L), the largest subunit of ribonucleotide reductase (ORF 38R), a putative viral membrane protein (ORF2L), a DNA packaging protein (ORF 1R), a putative serine/threonine kinase (ORF 57R), a putative RAD2-like DNA repair protein (ORF 95R), a $129 \mathrm{kDa}$ protein of unknown function (ORF 41R), and the viral DMTase (ORF 83R) are ongoing and have demonstrated reductions in viral yields ranging from $41-92 \%$ [123]. However, unlike the first study in which KD of MCP, vPOL-II $\alpha$, and 18K was confirmed by 1D SDS-polyacrylamide gel electrophoresis, we have been unable to identify unambiguously the targeted protein in these latest studies, and thus do not know if the partial reductions in virus yields reflect the non-essential nature of the gene product or incomplete KD of the targeted protein. To overcome this problem, recombinant viral proteins will be generated and used to produce polyclonal antibodies for Western blot and immunofluorescent analyses. Lastly, although asMOs can be powerful tools for uncovering viral gene function, their use is potentially limited by the nature of some ranavirus mRNAs. Because many FV3 transcripts possess very short, AU-rich 5' non-translated regions, and because sequences surrounding the AUG initiation codon may be unfavorable for targeting due to, for example, high AU content or secondary structure, asMO-mediated KD approaches may not succeed with all targeted genes. In these cases, siRNA-mediated KD or KO approaches, discussed below, provide alternative approaches. Nevertheless, despite these limitations, asMOs have provided insight into the roles of several FV3 genes and will continue to be a useful tool for elucidating viral gene function in vitro. Together with anti-viral antibodies to confirm knock down and identify intracellular locations, these studies will broaden our understanding of the complex story of virus-host interactions.

\subsection{Knock Down of Viral Gene Expression Using siRNA}

As an alternative to asMOs, siRNAs have also been used in a limited number of cases to knock down iridovirid gene expression [48,122,124,125]. While knock down has been achieved, we observed that inhibition of FV3 gene expression only took place if cells were infected at low multiplicities of infection, i.e., $<0.1 \mathrm{PFU} /$ cell. Similar to the situation in some other viral systems, the inverse relationship between multiplicity of infection and siRNA knockdown suggests that a virion-associated or virus-encoded protein may block siRNA-mediated knockdown by either binding or degrading 
siRNA [126]. To date, expression of FV3 transcripts encoding MCP, DMTase, and vPOL-II $\alpha$ have been knocked down by siRNA and resulted in a marked inhibition of replication.

\subsection{Knock out Approaches to Elucidate Viral Gene Function}

A powerful and potentially more useful approach to elucidate viral gene function involves the generation of knock out $(\mathrm{KO})$ mutants since, in contrast to transient $\mathrm{KD}$ triggered by asMOs or siRNAs, the phenotypes of KO mutants can be evaluated both in vitro and in vivo. This feature makes KO mutants especially useful for identifying viral genes that play roles in immune evasion and virulence. KO mutants have been used extensively to elucidate the function of various poxviruses genes [127-129], and methodology developed here has been adapted to ranaviruses. However, despite using poxviruses as a guide, ranavirus $\mathrm{KO}$ mutants, using homologous recombination to replace the targeted gene with a selectable marker, have only recently been isolated. The reasons for the difficulty in applying this approach to ranaviruses are not clear, but may reflect the presence of a ranavirus-encoded endonuclease that cleaves unmethylated DNA [30,38]. If correct, introduction of unmethylated plasmid DNA, bearing the selectable marker, into a virus-infected cell may lead to degradation of the majority of plasmid DNA and make recombination unlikely. As was done previously in a recombinant BIV vector [130,131], positioning the selectable marker, e.g., the neomycin-resistance gene, downstream of the promoter for the $18 \mathrm{~K}$ immediate early (IE) gene drove high levels of expression of the resistance gene and permitted isolation of rare recombinants.

The first ranavirus KO mutant targeted the ATV-encoded homolog of eukaryotic translational initiation factor $2 \alpha$ (vIF-2 $\alpha$ ) [132]. As discussed above, following virus infection, host cells activate PKR, an interferon (IFN) inducible double-stranded RNA activated protein kinase [133], that, in turn, phosphorylates the $\alpha$ subunit of eIF-2 and, as a consequence, inhibits both host and viral protein synthesis. To prevent translational shut-off, several viruses, including most ranaviruses, encode an eIF-2 $\alpha$ homolog that has been proposed to function as a pseudosubstrate for PKR [134]. In vaccinia virus this homolog is designated $\mathrm{K} 3 \mathrm{~L}$, whereas in ranaviruses it is termed vIF-2 $\alpha$. Although K3L and vIF-2 $\alpha$ differ markedly in size, they share a common sequence motif (VDRVDREKGYVDL) that is likely required for activity. In this scenario, PKR binds K3L/vIF-2 $\alpha$ instead of eIF-2 $\alpha$, and as a consequence eIF- $2 \alpha$ is not phosphorylated and protein synthesis is maintained. To determine if ATV vIF-2 $\alpha$ (ORF 57R) is functionally similar to K3L, the ranavirus gene was replaced with a selectable marker, the neomycin resistance $(N e o R)$ gene. To generate an ATV KO mutant, NeoR was inserted downstream of the ATV $18 \mathrm{~K}$ IE promoter and this construct was bracketed with sequences identical to those in the flanking region of the targeted gene. A PCR product bearing this construct was then transfected into BF-2 cells and infected with wild-type (wt) ATV. Recombinant virus was isolated by selective growth in the presence of neomycin, and replication of the KO mutant was compared to wt virus in vitro and in vivo. The KO mutant, designated ATV $\triangle 57 \mathrm{R}$, replicated to titers comparable to that of wt ATV in vitro, but had a small plaque phenotype. In addition, ATV $\Delta 57 \mathrm{R}$ was 8-fold more sensitive to IFN than wt ATV. The increased IFN sensitivity of ATV $\triangle 57 \mathrm{R}$ was correlated with the increased phosphorylation of eIF- $2 \alpha$ and the lack of PKR degradation. In contrast, wt ATV degraded PKR and inhibited cellular eIF- $2 \alpha$ phosphorylation. In addition, ATV $\Delta 57 \mathrm{R}$ was less pathogenic than wt ATV following infection of tiger salamanders (Ambystoma tigrinum) indicating that vIF-2 $\alpha$ was a 
likely viral virulence/immune evasion protein. Thus the ATV vIF- $2 \alpha$ gene is a putative IFN-resistance gene that inhibits cellular innate immune responses by degrading PKR and maintaining high levels of viral protein synthesis.

In an effort to improve the KO methodology, Chen et al. [135] recently developed a potentially more powerful dual selection method to generate KO mutants within FV3. In this system, the gene of interest is replaced, via homologous recombination, with a gene encoding the puromycin-resistance gene fused to the gene for Enhanced Green Fluorescent Protein (EGFP). In initial experiments KO mutants targeting the truncated vIF- $2 \alpha$ protein $(\mathrm{FV} 3-\Delta \mathrm{VIF}-2 \alpha)$ and the $18 \mathrm{~K}$ IE protein (FV3- $\Delta 18 \mathrm{~K}$ ) were generated as well as a control, "knock in" mutant in which the puromycin-resistance/EGFP gene was inserted into a non-coding portion of the genome. While all three recombinant viruses grew well in vitro, the vIF- $2 \alpha$ and $18 \mathrm{~K} \mathrm{KO}$ mutants, but not the control "knock in" mutant, showed a 90\% drop in virus levels in $X$. laevis tadpoles. These results confirmed the previous observation that the $18 \mathrm{~K}$ protein was not required for replication in vitro [52], and indicate that $18 \mathrm{~K}$ plays a role, albeit unknown, in replication in vivo. The finding that the truncated vIF-2 $\alpha$ protein of FV3 was also required for replication in vivo was surprising because the FV3 homolog of vIF- $2 \alpha$ is missing the N-terminal two-thirds of this protein, including the region homologous to vaccinia virus $\mathrm{K} 3 \mathrm{~L}$ and eukaryotic translational initiation factor $2 \alpha$. Inspection of the FV3 nucleotide sequence indicated that FV3 vIF-2 $\alpha$ is a chimeric protein resulting from deletion and in-frame fusion of a small upstream ORF with the larger, downstream vIF-2 $\alpha$ ORF. The resulting product contains 10 amino acids from the N-terminus of the upstream ORF and the last 65 amino acids of the full-length vIF-2 $\alpha$ protein. The reduced replication of FV3- $\Delta$ vIF- $2 \alpha$ in vivo suggests that the C-terminal end of the FV3 vIF-2 $\alpha$ homolog is required for full replication in vivo. In addition to the above KO mutants, a recombinant soft-shelled turtle iridovirus has recently been constructed that expresses EGFP. EGFP-expressing mutants may provide an alternative, simplified strategy for screening antiviral substrates through the visualization and quantification of fluorescent virus [136].

\subsection{Assessment of Viral Gene Function by Analysis of Recombinant Viral Proteins}

In contrast to the above studies, a fourth approach for determining viral gene function involves the synthesis of recombinant viral proteins and assessment of their functions in vivo and in vitro. Several investigators have used this approach and representative examples are discussed below.

\subsubsection{ICP46}

A putative homolog of FV3 ICP46 was identified in SGIV [137]. ICP46 (mol wt $44.1 \mathrm{kDa}$ ) is an IE gene product that is distributed predominantly within the cytoplasm but is also found within virions. A plasmid expressing ICP46 was introduced into grouper embryonic (GP) and fathead minnow cells and stably transfected cells were characterized. Over expression of SGIV ICP46 resulted in higher cell densities and increased growth of monolayer cultures. SGIV replication was compared in GP cells transfected with an empty vector and in GP cells expressing ICP46. SGIV replicated more rapidly and reached titers that were 10-fold higher in ICP46 expressing cells than in control cells. Although conserved domains suggestive of function were not detected within ICP46, the authors speculate, based on the above results, that ICP46 might encode a protein involved in cell growth control. The 
authors suggested that ICP46, like IE proteins in other viral systems, might control host cell growth by regulating the cell cycle, preventing growth arrest, or delaying apoptosis and play a critical role in promoting a proliferative environment that enhances virus replication.

\subsubsection{Viral Vascular Endothelial Growth Factor}

ISKNV (genus Megalocytivirus) ORF 48R encodes a viral protein with marked similarity to vascular endothelial growth factor (vVEGF) [138]. Microinjection of a plasmid expressing vVEGF into zebrafish one-cell embryos resulted in pericardial edema and dilation of the tail region suggesting that vVEGF triggers vascular permeability. Moreover, vVEGF binds and up-regulates the expression of FLK-1 and together both proteins likely contribute to the proliferative and highly vascularized nature of ISKNV lesions in its natural host, the Chinese mandarin fish. Although these results suggest that ISKNV ORF48R plays a vital role in host infection and viral replication, its precise function remains unclear. Following Orf virus (family Poxviridae) infection, the vVEGF homolog aids in scab formation and wound healing and may enhance transmission since scabs contains substantial amounts of infectious virus.

\subsubsection{Histone Binding Protein}

A novel histone-binding protein was identified in SGIV by structural analysis of the ORF 158L gene product [139]. X-ray diffraction analysis of recombinant 158L determined the crystal structure at a resolution of $2.2 \AA$, and revealed that $158 \mathrm{~L}$ exhibited partial structural resemblance to the histone-binding region of anti-silencing factor 1 (Asf1), a histone $\mathrm{H} 3 / \mathrm{H} 4$ chaperon. Using recombinant 158L protein, interaction was demonstrated between $158 \mathrm{~L}$ and histone $\mathrm{H} 3 / \mathrm{H} 4$ complexes and $\mathrm{H} 3$ by isothermal titration calorimetry. The authors suggested that $158 \mathrm{~L}$ may be involved in both the regulation and expression of histone $\mathrm{H} 3$ and $\mathrm{H} 4$ methylation, events which allow the virus to control host cell gene expression and facilitate viral replication.

\subsubsection{SGIV $18 \mathrm{~K}$}

SGIV ORF 86R encodes a homolog of the FV3 $18 \mathrm{~K}$ immediate early protein. Although KD studies using an asMO targeted against $18 \mathrm{~K}$ [52] and an 18K knock out mutant [135] indicated that expression of $18 \mathrm{~K}$ was not required for replication in either FHM or BHK cells, replication of the $18 \mathrm{~K} \mathrm{KO}$ in Xenopus laevis tadpoles was reduced about 10 -fold compared to wt virus or a "knock in" mutant. To determine the intracellular location of the $18 \mathrm{~K}$ gene product, Xia et al. [140] generated recombinant SGIV $18 \mathrm{~K}$ protein and used it to produce rabbit anti-18K serum. Immunofluorescent assay showed SGIV $18 \mathrm{~K}$ to be distributed within the cytoplasm adjacent to VAS and nuclei, and Western blotting using purified and disrupted virions indicated $18 \mathrm{~K}$ was a non-envelope virion-associated protein. Transfection of uninfected grouper cells with a vector expressing $18 \mathrm{~K}$ enhanced cellular growth rates and led to an increase in the density of monolayer cultures. Moreover, SGIV replication in cultures expressing $18 \mathrm{~K}$ were about 10 -fold higher than in cultures transfected with an empty vector. The authors suggest that $18 \mathrm{~K}$ may be a protein that plays a role in the control of cellular growth and thus indirectly enhances SGIV replication. However, because virus yields were expressed as $\mathrm{TCID}_{50} / \mathrm{mL}$, it 
was not clear if the increase in SGIV yield reflected higher virus production per cell or simply equivalent cellular yields in cultures containing varying numbers of cells.

\subsection{5. $v I F-2 \alpha$}

Rothenburg et al. [61] cloned the vIF-2 $\alpha$ gene from Rana catesbeiana virus Z (RCV-Z) into an expression vector and examined its function in a yeast-based assay system. Yeast expressing human PKR failed to grow due to the toxicity of the PKR protein. However, yeast expressing vIF-2 $\alpha$, or the vaccinia virus K3L protein, suppressed the toxic effects of human PKR indicating that vIF-2 $\alpha$ was functionally equivalent to the vaccinia virus protein. Subsequent work showed that whereas K3L was effective only against human PKR, vIF-2 $\alpha$ suppressed the toxic effects of both human and zebrafish PKR suggesting that PKR antagonists evolved to protect physiologically-relevant/phylogeneticallyrelated targets. In addition, a study using vectors expressing the various domains of vIF-2 $\alpha$, i.e., $\mathrm{N}$-terminal, central/helical, and $\mathrm{C}$-terminal, demonstrated that the $\mathrm{N}$-terminal and central/helical domains were sufficient for suppressing PKR toxicity. Collectively, these results provide the first formal proof that vIF-2 $\alpha$ functions as a virus-encoded PKR antagonist.

\subsubsection{Additional Studies Using Recombinant Iridovirid Proteins}

Recombinant versions of thymidylate synthase (LCDV-China), ERV1 (Rana grylio virus, RGV), dUTPase (RGV), RNAse III (RBIV), and LITAF (SGIV) were generated and evaluated for their ability to influence cellular growth, enhance virus replication, induce apoptosis, and cleave dsRNA $[51,75,141,142]$. Recombinant thymidylate synthase from LCDV-China was found to promote cell cycle progression and produced a transformed phenotype [143]. Antibodies directed against Rana gyrlio virus (RGV) ERV1 detected ERV1 expression within the cytoplasm and nucleus, but not within VAS; transcript analysis indicated that ERV1 was a late viral gene product [141]. RGV dUTPase was determined to be a DE gene product that was localized to the cytoplasm. Ectopic expression did not enhance virus replication, however, its effect on cellular proliferation was not examined [51]. Recombinant RNAse III from RBIV cleaved dsRNA, but the salt optimum for cleavage was inconsistent with a physiological effect [75]. The authors speculated that RNAse III might play a role in the suppression of RNA interference, as has been suggested for other viral dsRNA-binding proteins, or could be involved in the processing of viral RNA. Lastly, Huang et al. [142] demonstrated that the SGIV homolog of LITAF (lipopolysaccharide-induced TNF- $\alpha$ factor) was a DE viral gene product. LITAF was located within the cytoplasm and was associated with mitochondria. When over-expressed ectopically, it led to the activation of caspase 3 and the induction of apoptosis. Collectively, ts mutants, asMO- and siRNA-mediated knock down, gene knock out, and recombinant protein studies are slowly elucidating the function of iridovirid genes and providing a clearer and more complete picture of how those genes enhance viral replication and modulate cellular functions.

\section{Future Directions}

Future studies of ranaviruses and other iridoviruses infecting ectothermic animals will focus on the following areas: (1) identifying and elucidating the function of replicative genes and those contributing 
to virulence, host range, and immune evasion; (2) understanding the correlates of antiviral immunity in an effort to understand the cellular and molecular basis of anti-viral immunity and to protect endangered and commercially important species from infection; (3) determining the impact of iridovirus infections in nature, defining viral host range, identifying susceptible hosts and reservoir species; (4) understanding how intrinsic (e.g., host immune suppression, host MHC repertoire, etc.) and extrinsic (e.g., habitat disruption, environmental stress, introduction of invasive species, etc.) factors influence the clinical outcomes of iridovirus infection. For example, determining whether iridovirids encode viral immune evasion proteins and how these proteins circumvent host immunity will highlight events at the interface of virology and immunology, and may identify possible targets for viral attenuation. Successful completion of these studies will involve the interactive efforts of virologists, immunologists, population biologists, ecologists, and veterinary pathologists. The Global Ranavirus Consortium [144] is but one interactive group of scientists interested in the role of infectious agents in population declines. Moreover, it is anticipated that general principles learned through study of iridovirus infections will be applicable to the study of other pathogens of cold-blooded vertebrates.

\section{Acknowledgments}

We would like to thank Robert Sample for the electron micrographs shown in Figure 1 and the artwork depicted in Figure 2. The work was partially supported by NSF award No. IOS 07-42711.

\section{Conflict of Interest}

The authors declare no conflict of interest.

\section{References and Notes}

1. Chinchar, V.G. Ranaviruses (family Iridoviridae): emerging cold-blooded killers. Arch. Virol. 2002, 147, 447-470.

2. Chinchar, V.G.; Hyatt, A.; Miyazaki, T.; Williams, T. Family Iridoviridae: poor viral relations no longer. Curr. Top. Microbiol. Immunol. 2009, 328, 123-170.

3. Jancovich, J.; Chinchar, V.G.; Hyatt, A.; Miyazaki, T.; Williams, T.; Zhang, Q.-Y. Family Iridoviridae. Virus Taxonomy: 9th Report of the International Committee on Taxonomy of Viruses; King, A.M.Q, Lefkowitz, E., Adams, M.J., Carstens, E.B., Eds.; Elsevier: San Diego, CA, USA, 2011.

4. Iyer, L.M.; Balaji, S.; Koonin, E.V.; Aravind, L. Evolutionary genomics of nucleo-cytoplasmic large DNA viruses. Virus Res. 2006, 117, 156-184.

5. Iyer, L.M.; Aravind, L.; Koonin, E.V. Common origin of four diverse families of large eukaryotic DNA viruses. J. Virol. 2001, 75, 11720-11734.

6. Yutin, N.; Koonin, E.V. Evolution of DNA ligases of nucleo-cytoplasmic large DNA viruses of eukaryotes: a case of hidden complexity. Biol. Direct 2009, 4, 51.

7. Yutin, N.; Wolf, Y.I.; Raoult, D.; Koonin, E.V. Eukaryotic large nucleo-cytoplasmic DNA viruses: Clusters of orthologous genes and reconstruction of viral genome evolution. Virol. J. 2009, 6, 223. 
8. Song, W.J.; Qin, Q.W.; Qiu, J.; Huang, C.H.; Wang, F.; Hew, C.L. Functional genomics analysis of Singapore grouper iridovirus: Complete sequence determination and proteomic analysis. J. Virol. 2004, 78, 12576-12590.

9. Just, F.; Essbauer, S.; Ahne, W.; Blahak, S. Occurrence of an invertebrate iridescent-like virus (Iridoviridae) in reptiles. J. Vet. Med. B Infect. Dis. Vet. Public Health 2001, 48, 685-694.

10. Weinmann, N.; Papp, T.; Alves de Matos, P.; Teifke, J.B.; Marschang, R.E. Experimental infection of crickets (Gryllus bimaculatus) with an invertebrate iridovirus isolated from the high casqued chameleon (Chamaeleo hoenelii). J. VET. Diagn. Invest. 2007, 19, 674-679.

11. Eaton, H.E.; Metcalf, J.; Penny, E.; Tcherepanov, V.; Upton, C.; Brunetti, C.R. Comparative genomic analysis of the family Iridoviridae: Re-annotating and defining the core set of iridovirus genes. Virol. J. 2007, 4, 11.

12. Jancovich, J.K.; Bremont, M.; Touchman, J.W.; Jacobs, B.L. Evidence for multiple recent host species shifts among the Ranaviruses (family Iridoviridae). J. Virol. 2010, 84, 2636-2647.

13. Wong, C.K.; Young, V.L.; Kleffmann, T.; Ward, V.K. Genomic and proteomic analysis of invertebrate iridovirus type 9. J. Virol. 2011, 85, 7900-7911.

14. Shi, C.Y.; Jia, K.T.; Yang, B.; Huang, J. Complete genome sequence of a megalocytivirus (family Iridoviridae) associated with turbot mortality in China. Virol. J. 2010, 7, 159.

15. Williams, T. The iridoviruses. Adv. Virus Res. 1996, 46, 345-412.

16. Devauchelle, G.; Stoltz, D.B.; Darcy-Tripier, F. Comparative ultrastructure of iridoviridae. Curr. Top. Microbiol. Immunol. 1985, 116, 1-21.

17. Yan, X.; Yu, Z.; Zhang, P.; Battisti, A.J.; Holdaway, H.A.; Chipman, P.R.; Bajaj, C.; Bergoin, M.; Rossmann, M.G.; Baker, T.S. The capsid proteins of a large, icosahedral dsDNA virus. J. Mol. Biol. 2009, 385, 1287-1299.

18. Mao, J.; Tham, T.N.; Gentry, G.A.; Aubertin, A.; Chinchar, V.G. Cloning, sequence analysis, and expression of the major capsid protein of the iridovirus frog virus 3. Virology 1996, 216, 431-436.

19. Mao, J.; Hedrick, R.P.; Chinchar, V.G. Molecular characterization, sequence analysis, and taxonomic position of newly isolated fish iridoviruses. Virology 1997, 229, 212-220.

20. Whitley, D.S.; Yu, K.; Sample, R.C.; Sinning, A.; Henegar, J.; Norcross, E.; Chinchar, V.G. Frog virus 3 ORF 53R, a putative myristoylated membrane protein, is essential for virus replication in vitro. Virology 2010, 405, 448-456.

21. Yan, Y.; Cui, H.; Jiang, S.; Huang, Y.; Huang, X.; Wei, S.; Xu, W.; Qin, Q. Identification of a novel marine fish virus, Singapore grouper iridovirus-encoded microRNAs expressed in grouper cells by Solexa sequencing. PLoS One 2011, 6, e19148.

22. Majji, S.; Thodima, V.; Sample, R.; Whitley, D.; Deng, Y.; Mao, J.; Chinchar, V.G. Transcriptome analysis of Frog virus 3, the type species of the genus Ranavirus, family Iridoviridae. Virology 2009, 391, 293-303.

23. Teng, Y.; Hou, Z.; Gong, J.; Liu, H.; Xie, X.; Zhang, L.; Chen, X.; Qin, Q.W. Whole-genome transcriptional profiles of a novel marine fish iridovirus, Singapore grouper iridovirus (SGIV) in virus-infected grouper spleen cell cultures and in orange-spotted grouper, Epinephulus coioides. Virology 2008, 377, 39-48.

24. Chen, L.M.; Wang, F.; Song, W.; Hew, C.L. Temporal and differential gene expression of Singapore grouper iridovirus. J. Gen. Virol. 2006, 87, 2907-2915. 
25. Williams, T.; Barbosa-Solomieu, V.; Chinchar, V.G. A decade of advances in iridovirus research. Adv. Virus Res. 2005, 65, 173-248.

26. Braunwald, J.; Nonnenmacher, H.; Tripier-Darcy, F. Ultrastructural and biochemical study of frog virus 3 uptake by BHK-21 cells. J. Gen. Virol. 1985, 66, 283-293.

27. Braunwald, J.; Tripier, F.; Kirn, A. Comparison of the properties of enveloped and naked frog virus 3 (FV3) particles. J. Gen. Virol. 1979, 45, 673-682.

28. Gendrault, J.L.; Steffan, A.M.; Bingen, A.; Kirn, A. Penetration and uncoating of frog virus 3 (FV3) in cultured rat Kupffer cells. Virology 1981, 112, 375-384.

29. Guo, C.J.; Liu, D.; Wu, Y.Y.; Yang, X.B.; Yang, L.S.; Mi, S.; Huang, Y.X.; Luo, Y.W.; Jia, K.T.; Liu, Z.Y.; et al. Entry of Tiger Frog Virus (an Iridovirus) into HepG2 Cells via a pH-Dependent, Atypical, Caveola-Mediated Endocytosis Pathway. J. Virol. 2011, 85, 6416-6426.

30. Tan, W.G.; Barkman, T.J.; Gregory Chinchar, V.; Essani, K. Comparative genomic analyses of frog virus 3, type species of the genus Ranavirus (family Iridoviridae). Virology 2004, 323, 70-84.

31. He, J.G.; Lu, L.; Deng, M.; He, H.H.; Weng, S.P.; Wang, X.H.; Zhou, S.Y.; Long, Q.X.; Wang, X.Z.; Chan, S.M. Sequence analysis of the complete genome of an iridovirus isolated from the tiger frog. Virology 2002, 292, 185-197.

32. Willis, D.B.; Goorha, R.; Granoff, A. Nongenetic reactivation of frog virus 3 DNA. Virology 1979, 98, 476-479.

33. Goorha, R.; Murti, G.; Granoff, A.; Tirey, R. Macromolecular synthesis in cells infected by frog virus 3. VIII. The nucleus is a site of frog virus 3 DNA and RNA synthesis. Virology 1978, 84, $32-50$.

34. Goorha, R. Frog virus 3 requires RNA polymerase II for its replication. J. Virol. 1981, 37, 496-499.

35. Willis, D.B.; Granoff, A. Transactivation of an immediate-early frog virus 3 promoter by a virion protein. J. Virol. 1985, 56, 495-501.

36. Goorha, R. Frog virus 3 DNA replication occurs in two stages. J. Virol. 1982, 43, 519-528.

37. Goorha, R.; Granoff, A.; Willis, D.B.; Murti, K.G. The role of DNA methylation in virus replication: inhibition of frog virus 3 replication by 5-azacytidine. Virology 1984, 138, 94-102.

38. Willis, D.B.; Goorha, R.; Granoff, A. DNA methyltransferase induced by frog virus 3. J. Virol. 1984, 49, 86-91.

39. Murti, K.G.; Porter, K.R.; Goorha, R.; Ulrich, M.; Wray, G. Interaction of frog virus 3 with the cytomatrix. II. Structure and composition of the virus assembly site. Exp. Cell Res. 1984, 154, 270-282.

40. Murti, K.G.; Goorha, R.; Granoff, A. An unusual replication strategy of an animal iridovirus. Adv. Virus Res. 1985, 30, 1-19.

41. Suarez, C.; Salas, M.L.; Rodriguez, J.M. African swine fever virus polyprotein pp62 is essential for viral core development. J. Virol. 2010, 84, 176-187.

42. Andres, G.; Alejo, A.; Salas, J.; Salas, M.L. African swine fever virus polyproteins pp220 and pp62 assemble into the core shell. J. Virol. 2002, 76, 12473-12482.

43. Goorha, R.; Murti, K.G. The genome of frog virus 3, an animal DNA virus, is circularly permuted and terminally redundant. Proc. Natl. Acad. Sci. U. S. A. 1982, 79, 248-252. 
44. Yang, K.; Baines, J.D. Tryptophan residues in the portal protein of herpes simplex virus 1 critical to the interaction with scafford protreins and incorporation of the portal into capsids. J. Virol. 2009, 83, 11726-11733.

45. Chang, J.T.; Schmid, M.F.; Rixon, F.J.; Chiu, W. Electron cryotomography reveals the portal in the herpesvirus capsid. J. Virol. 2007, 81, 2065-2068.

46. Zauberman, N.; Mutsafi, Y.; Ben Halevy, D.; Shimoni, E.; Klein, E.; Xiao, C.Y.; Sun, S.; Minsky, A. Distinct DNA exit and packaging portals in the virus Acanthamoeba polyphaga mimivirus. PLoS Biol. 2008, 6, e114.

47. Chinchar, V.G.; Granoff, A. Temperature-sensitive mutants of frog virus 3: biochemical and genetic characterization. J. Virol. 1986, 58, 192-202.

48. Kim, Y.S.; Ke, F.; Lei, X.Y.; Zhu, R.; Zhang, Q.Y. Viral envelope protein 53R gene highly specific silencing and iridovirus resistance in fish cells by AmiRNA. PLoS One 2010, 5, e10308.

49. Zhao, Z.; Ke, F.; Huang, Y.H.; Zhao, J.G.; Gui, J.F.; Zhang, Q.Y. Identification and characterization of a novel envelope protein in Rana grylio virus. J. Gen. Virol. 2008, 89, 1866-1872.

50. Chinchar, V.G.; Granoff, A. Isolation and characterization of a frog virus 3 variant resistant to phosphonoacetate: genetic evidence for a virus-specific DNA polymerase. Virology 1984, 138, 357-361.

51. Zhao, Z.; Ke, F.; Gui, J.; Zhang, Q. Characterization of an early gene encoding for dUTPase in Rana grylio virus. Virus Res. 2007, 123, 128-137.

52. Sample, R.; Bryan, L.; Long, S.; Majji, S.; Hoskins, G.; Sinning, A.; Olivier, J.; Chinchar, V.G. Inhibition of iridovirus protein synthesis and virus replication by antisense morpholino oligonucleotides targeted to the major capsid protein, the $18 \mathrm{kDa}$ immediate-early protein, and a viral homolog of RNA polymerase II. Virology 2007, 358, 311-320.

53. Su, H.-P.; Lin, D.Y.-W.; Garboczi, D.N. The structure of G4, the poxvirus disulfide oxidoreductase essential for virus maturation and infectivity. J. Virol. 2006, 80, 7706-7713.

54. Chinchar, V.G.; Robert, J.; Storfer, A.T. Ecology of viruses infecting ectothermic vertebrates - the impact of ranavirus infections on amphibians. In Studies in Viral Ecology; Hurst, C.J., Ed.; WileyBlackwell: Hoboken, New Jersey, USA, 2011; Volume 2, pp. 231-260

55. Raghow, R.; Granoff, A. Macromolecular synthesis in cells infected by frog virus 3. X. Inhibition of cellular protein synthesis by heat-inactivated virus. Virology 1979, 98, 319-327.

56. Chinchar, V.G.; Dholakia, J.N. Frog virus 3-induced translational shut-off: activation of an eIF-2 kinase in virus-infected cells. Virus Res. 1989, 14, 207-223.

57. Chinchar, V.G.; Yu, W. Frog virus 3-mediated translational shut-off: frog virus 3 messages are translationally more efficient than host and heterologous viral messages under conditions of increased translational stress. Virus Res. 1990, 16, 163-174.

58. Chinchar, V.G.; Bryan, L.; Wang, J.; Long, S.; Chinchar, G.D. Induction of apoptosis in frog virus 3-infected cells. Virology 2003, 306, 303-312.

59. Chinchar, V.G.; Caughman, G.B. Heat-inactivated frog virus 3 selectively inhibits equine herpesvirus type 1 translation in a temporal class-dependent manner. Virology 1986, 152, 466-471. 
60. Chinchar, V.G.; Yu, W. Translational efficiency: iridovirus early mRNAs outcompete tobacco mosaic virus message in vitro. Biochem. Biophys. Res. Commun. 1990, 172, 1357-1363.

61. Rothenburg, S.; Chinchar, V.G.; Dever, T.E. Characterization of a ranavirus inhibitor of the antiviral protein kinase PKR. BMC Microbiol. 2011, 11, 56.

62. Langland, J.O.; Jacobs, B.L. The role of the PKR-inhibitory genes, E3L and K3L, in determining vaccinia virus host range. Virology 2002, 299, 133-141.

63. Majji, S.; LaPatra, S.; Long, S.M.; Sample, R.; Bryan, L.; Sinning, A.; Chinchar, V.G. Rana catesbeiana virus Z (RCV-Z): a novel pathogenic ranavirus. Dis. Aquat. Org. 2006, 73, 1-11.

64. Essbauer, S.; Bremont, M.; Ahne, W. Comparison of the eIF-2alpha homologous proteins of seven ranaviruses (Iridoviridae). Virus Genes 2001, 23, 347-359.

65. Reading, P.C.; Moore, J.B.; Smith, G.L. Steroid hormone synthesis by vaccinia virus suppresses the inflammatory response to infection. J. Exp. Med. 2003, 197, 1269-1278.

66. Moore, J.B.; Smith, G.L. Steroid hormone synthesis by a vaccinia enzyme: a new type of virus virulence factor. EMBO J. 1992, 11, 3490.

67. Besch, R.; Poeck, H.; Hohenauer, T.; Senft, D.; Hacker, G.; Berking, C.; Hornung, V.; Endres, S.; Ruzicka, T.; Rothenfusser, S.; et al. Proapoptotic signaling induced by RIG-I and MDA-5 results in type I interferon-independent apoptosis in human melanoma cells. J. Clin. Investig. 2009, 119, 2399-2411.

68. Bouchier-Hayes, L.; Hartin, S.J. CARD games in apoptosis and immunity. EMBO Rep. 2002, 3, 616-621.

69. Hofmann, K.; Bucher, P.; Tschopp, J. The CARD domain: a new apoptotic signalling motif. Trends Biochem. Sci. 1997, 22, 155-156.

70. Lei, Y.; Moore, C.B.; Liesman, R.M.; O'Connor, B.P.; Bergstralh, D.T.; Chen, Z.J.; Pickles, R.J.; Ting, J.P. MAVS-mediated apoptosis and its inhibition by viral proteins. PLoS One 2009, 4, e5466.

71. Yoneyama, M.; Kikuchi, M.; Natsukawa, T.; Shinobu, N.; Imaizumi, T.; Miyagishi, M.; Taira, K.; Akira, S.; Fujita, T. The RNA helicase RIG-I has an essential function in double-stranded RNAinduced innate antiviral responses. Nat. Immunol. 2004, 5, 730-737.

72. Hausmann, S.; Marq, J.B.; Tapparel, C.; Kolakofsky, D.; Garcin, D. RIG-I and dsRNA-induced IFNbeta activation. PLoS One 2008, 3, e3965.

73. Levy, D.E.; Marie, I.J. RIGging an antiviral defense-It's in the CARDs. Nat. Immunol. 2004, 5, 699-701.

74. Meylan, E.; Curran, J.; Hofmann, K.; Moradpour, D.; Binder, M.; Bartenschlager, R.; Tschopp, J. Cardif is an adaptor protein in the RIG-I antiviral pathway and is targeted by hepatitis $\mathrm{C}$ virus. Nature 2005, 437, 1167-1172.

75. Zenke, K.; Kim, K.H. Functional characterization of the RNase III gene of rock bream iridovirus. Arch. Virol. 2008, 153, 1651-1656.

76. Johnston, J.B.; McFadden, G. Poxvirus immunomodulatory strategies: Current perspectives. J. Virol. 2003, 77, 6093-6100.

77. Seet, B.T.; Johnston, J.B.; Brunetti, C.R.; Barrett, J.W.; Everett, H.; Cameron, C.; Sypula, J.; Nazarian, S.H.; Lucas, A.; McFadden, G. Poxviruses and immune evasion. Annu. Rev. Immunol. 2003, 21, 377-423. 
78. Barrett, J.W.; Alston, L.R.; Wang, F.; Stanford, M.M.; Gilbert, P.A.; Gao, X.; Jimenez, J.; Villeneuve, D.; Forsyth, P.; McFadden, G. Identification of host range mutants of myxoma virus with altered oncolytic potential in human glioma cells. J. Neurovirol. 2007, 13, 549-560.

79. Daikoku, T.; Yamamoto, N.; Maeno, K.; Nishiyama, Y. Role of viral ribonucleotide reductase in the increase of dTTP pool size in herpes simplex virus-infected Vero cells. J. Gen. Virol. 1991, $72,1441-1444$.

80. de Wind, N.; Berns, A.; Gielkens, A.; Kimman, T. Ribonucleotide reductase-deficient mutants of pseudorabies virus are avirulent for pigs and induce partial protective immunity. J. Gen. Virol. 1993, 74, 351-359.

81. Oliveros, M.; Garcia-Escudero, R.; Alejo, A.; Vinuela, E.; Salas, M.L.; Salas, J. African swine fever virus dUTPase is a highly specific enzyme required for efficient replication in swine macrophages. J. Virol. 1999, 73, 8934-8943.

82. Ting, J.W.; Wu, M.F.; Tsai, C.T.; Lin, C.C.; Guo, I.C.; Chang, C.Y. Identification and characterization of a novel gene of grouper iridovirus encoding a purine nucleoside phosphorylase. J. Gen. Virol. 2004, 85, 2883-2892.

83. Jancovich, J.K.; Mao, J.; Chinchar, V.G.; Wyatt, C.; Case, S.T.; Kumar, S.; Valente, G.; Subramanian, S.; Davidson, E.W.; Collins, J.P.; et al. Genomic sequence of a ranavirus (family Iridoviridae) associated with salamander mortalities in North America. Virology 2003, 316, 90-103.

84. Buller, R.M.; Arif, B.M.; Black, D.M.; Dumbell, K.R.; Esposito, J.J.; Lefkowitz, E.J.; McFadden, G.; Moss, B.; Mercer, A.A.; Moyer, R.M.; et al. Poxviridae. Virus Taxonomy: Eighth Report of the International Committee on Taxonomy of Viruses; Fauquet, C.M., Mayo, M.A., Maniloff, J., Desselberger, U., Ball, L.A., Eds.; Elsevier: San Diego, CA, USA, 2005; pp. 117-133.

85. Lefkowitz, E.J.; Wang, C.; Upton, C. Poxviruses: past, present, and future. Virus Res. 2006, 117, 105-118.

86. Mezencev, R.; Mereish, K. How similar are poxviruses? Science 2005, 308, 1259-1260.

87. Bandin, I.; Dopazo, C.P. Host range, host specificity and hypothesized host shift events among viruses of lower vertebrates. Vet. Res. 2011, 42, 67.

88. Schock, D.M.; Bollinger, T.K.; Chinchar, V.G.; Jancovich, J.K.; Collins, J.P. Experimental evidence that amphibian ranaviruses are multihost pathogens. Coepia 2008, 133-143.

89. Tamura, K.; Dudley, J.; Nei, M.; Kumar, S. MEGA4: Molecular Evolutionary Genetics Analysis (MEGA) software version 4.0. Mol. Biol. Evol. 2007, 24, 1596-1599.

90. Chen, G.; Robert, J. Antiviral Immunity in Amphibians. Viruses, submitted for publication, 2011.

91. Miller, D.B.; Gray, M.; Storfer, A.T. Ecopathology of Ranaviruses Infecting Amphibians. Viruses, submitted for publication, 2011.

92. Walker, P.J.; Winton, J.R. Emerging viral diseases of fish and shrimp. Vet. Res. 2010, 41, 51.

93. Whittington, R.J.; Becker, J.A.; Dennis, M.M. Iridovirus infections in finfish-Critical review with emphasis on ranaviruses. J. Fish Dis. 2010, 33, 95-122.

94. Mazzoni, R.; de Mesquita, A.J.; Fleury, L.F.; de Brito, W.M.; Nunes, I.A.; Robert, J.; Morales, H.; Coelho, A.S.; Barthasson, D.L.; Galli, L.; et al. Mass mortality associated with a frog virus 3-like Ranavirus infection in farmed tadpoles Rana catesbeiana from Brazil. Dis. Aquat. Org. 2009, 86, 181-191. 
95. Gray, M.J.; Miller, D.L.; Hoverman, J.T. Ecology and pathology of amphibian ranaviruses. Dis. Aquat. Org. 2009, 87, 243-266.

96. Gantress, J.; Maniero, G.D.; Cohen, N.; Robert, J. Development and characterization of a model system to study amphibian immune responses to iridoviruses. Virology 2003, 311, 254-262.

97. Maniero, G.D.; Morales, H.; Gantress, J.; Robert, J. Generation of a long-lasting, protective, and neutralizing antibody response to the ranavirus FV3 by the frog Xenopus. Dev. Comp. Immunol. 2006, 30, 649-657.

98. Morales, H.D.; Abramowitz, L.; Gertz, J.; Sowa, J.; Vogel, A.; Robert, J. Innate immune responses and permissiveness to ranavirus infection of peritoneal leukocytes in the frog Xenopus laevis. J. Virol. 2010, 84, 4912-4922.

99. Morales, H.D.; Robert, J. Characterization of primary and memory CD8 T-cell responses against ranavirus (FV3) in Xenopus laevis. J. Virol. 2007, 81, 2240-2248.

100. Robert, J.; Abramowitz, L.; Gantress, J.; Morales, H.D. Xenopus laevis: A possible vector of Ranavirus infection? J. Wildl. Dis. 2007, 43, 645-652.

101. Robert, J.; George, E.; De Jesus Andino, F.; Chen, G. Waterborne infectivity of the Ranavirus frog virus 3 in Xenopus laevis. Virology 2011, 417, 410-417.

102. Robert, J.; Morales, H.; Buck, W.; Cohen, N.; Marr, S.; Gantress, J. Adaptive immunity and histopathology in frog virus 3-infected Xenopus. Virology 2005, 332, 667-675.

103. Caipang, C.M.; Hirono, I.; Aoki, T. Immunogenicity, retention and protective effects of the protein derivatives of formalin-inactivated red seabream iridovirus (RSIV) vaccine in red seabream, Pagrus major. Fish Shellfish Immunol. 2006, 20, 597-609.

104. Caipang, C.M.; Takano, T.; Hirono, I.; Aoki, T. Genetic vaccines protect red seabream, Pagrus major, upon challenge with red seabream iridovirus (RSIV). Fish Shellfish Immunol. 2006, 21, 130-138.

105. Green, D.E.; Converse, K.A.; Schrader, A.K. Epizootiology of sixty-four amphibian morbidity and mortality events in the USA 1996-2001. Ann. N. Y. Acad. Sci. 2002, 969, 323-339.

106. Cullen, B.R.; Owens, L. Experimental challenge and clinical cases of Bohle iridovirus (BIV) in native Australian anurans. Dis. Aquat. Org. 2002, 49, 83-92.

107. Mao, J.; Green, D.E.; Fellers, G.; Chinchar, V.G. Molecular characterization of iridoviruses isolated from sympatric amphibians and fish. Virus Res. 1999, 63, 45-52.

108. Jensen, B.B.; Ersboll, A.K.; Ariel, E. Susceptibility of pike Esox lucius to a panel of Ranavirus isolates. Dis. Aquat. Org. 2009, 83, 169-179.

109. Moody, N.J.G.; Owens, L. Experimental demonstration of pathogenicity of a frog virus, Bohle iridovirus, for a fish species, barramundi Lates Calcarifer. Dis. Aquat. Org. 1994, 18, 95-102.

110. Willis, D.B.; Goorha, R.; Chinchar, V.G. Macromolecular synthesis in cells infected by frog virus 3. Curr. Top. Microbiol. Immunol. 1985, 116, 77-106.

111. Goorha, R.; Granoff, A. Icosahedral cytoplasmic deoxyriboviruses. Comprehensive Virology; Fraenkel-Conrat, H., Wagner, R.R., Eds.; Plenum Press: New York, NY, USA, 1979; Volume 14, pp. 347-399.

112. Naegele, R.F.; Granoff, A. Viruses and renal carcinoma of Rana pipiens. XI. Isolation of frog virus 3 temperature-sensitive mutants; complementation and genetic recombination. Virology 1971, 44, 286-295. 
113. Purifoy, D.; Naegele, R.F.; Granoff, A. Viruses and renal carcinoma of Rana pipiens. XIV. Temperature-sensitive mutants of frog virus 3 with defective encapsidation. Virology 1973, 54, 525-535.

114. Goorha, R.; Willis, D.B.; Granoff, A.; Naegele, R.F. Characterization of a temperature-sensitive mutant of frog virus 3 defective in DNA replication. Virology 1981, 112, 40-48.

115. Sample, R.C. Elucidation of Frog Virus 3 Gene Function and Pathways of Virion Formation. Ph.D. Thesis, University of Mississippi Medical Center, Jackson, MS, UA, 2010.

116. Chinchar, V.G.; Goorha, R.; Granoff, A. Early proteins are required for the formation of frog virus 3 assembly sites. Virology 1984, 135, 148-156.

117. Dagle, J.M.; Weeks, D.L. Oligonucleotide-based strategies to reduce gene expression. Differentiation 2001, 69, 75-82.

118. Hardy, S.; Legagneux, V.; Audic, Y.; Paillard, L. Reverse genetics in eukaryotes. Biol. Cell. 2010, 102, 561-580.

119. Neuman, B.W.; Stein, D.A.; Kroeker, A.D.; Paulino, A.D.; Moulton, H.M.; Iversen, P.L.; Buchmeier, M.J. Antisense morpholino-oligomers directed against the 5 ' end of the genome inhibit coronavirus proliferation and growth. J. Virol. 2004, 78, 5891-5899.

120. Deas, T.S.; Binduga-Gajewska, I.; Tilgner, M.; Ren, P.; Stein, D.A.; Moulton, H.M.; Iversen, P.L.; Kauffman, E.B.; Kramer, L.D.; Shi, P.Y. Inhibition of flavivirus infections by antisense oligomers specifically suppressing viral translation and RNA replication. J. Virol. 2005, 79, 4599-4609.

121. Lai, S.H.; Stein, D.A.; Guerrero-Plata, A.; Liao, S.L.; Ivanciuc, T.; Hong, C.; Iversen, P.L.; Casola, A.; Garofalo, R.P. Inhibition of respiratory syncytial virus infections with morpholino oligomers in cell cultures and in mice. Mol. Ther. 2008, 16, 1120-1128.

122. Whitley, D.S.; Sample, R.C.; Sinning, A.R.; Henegar, J.; Chinchar, V.G. Antisense approaches for elucidating ranavirus gene function in an infected fish cell line. Dev. Comp. Immunol. 2011, 35, 937-948.

123.Yu, E.K.; Whitley, D.S.; Chinchar, V.G. Department of Microbiology, University of Mississippi Medical Center, Jackson, MS. Unpublished work, 2011.

124.Dang, L.T.; Kondo, H.; Hirono, I.; Aoki, T. Inhibition of red seabream iridovirus (RSIV) replication by small interfering RNA (siRNA) in a cell culture system. Antivir. Res. 2008, 77, 142-149.

125. Xie, J.; Lu, L.; Deng, M.; Weng, S.; Zhu, J.; Wu, Y.; Gan, L.; Chan, S.M.; He, J. Inhibition of reporter gene and Iridovirus-tiger frog virus in fish cell by RNA interference. Virology 2005, 338, 43-52.

126. Hussain, M.; Abrahim, A.M.; Asgari, S. An ascovirus-encoded RNase III autoregulates its expression and suppresses RNA interference-mediated gene silencing. J. Virol. 2010, 84, 3624-3630.

127. Chakrabarti, S.; Brechling, K.; Moss, B. Vaccinia virus expression vector: Coexpression of betagalactosidase provides visual screening of recombinant virus plaques. Mol. Cell. Biol. 1985, 5, 3403-3409. 
128. Franke, C.A.; Rice, C.M.; Strauss, J.H.; Hruby, D.E. Neomycin resistance as a dominant selectable marker for selection and isolation of vaccinia virus recombinants. Mol. Cell. Biol. 1985, 5, 1918-1924.

129. Ward, B.M.; Weisberg, A.S.; Moss, B. Mapping and functional analysis of internal deletions within the cytoplasmic domains of the vaccinia virus A33R and A36R entry proteins J. Virol. 2003, 77, 4113-4126.

130. Pallister, J.; Goldie, S.; Coupar, B.; Hyatt, A. Promoter activity in the 5' flanking regions of the Bohle iridovirus ICP 18, ICP 46 and major capsid protein genes. Arch. Virol. 2005, 150, 1911-1919.

131. Pallister, J.; Goldie, S.; Coupar, B.; Shiell, B.; Michalski, W.P.; Siddon, N.; Hyatt, A. Bohle iridovirus as a vector for heterologous gene expression. J. Virol. Methods 2007, 146, 419-423.

132. Jancovich, J.K.; Jacobs, B.L. Innate immune evasion mediated by the Ambystoma tigrinum virus eukaryotic translation initiation factor 2 alpha homologue. J. Virol. 2011, 85, 5061-5069.

133. Samuel, C.E. The eIF-2 alpha protein kinases, regulators of translation in eukaryotes from yeast to humans. J. Biol. Chem. 1993, 268, 7603-7606.

134. Langland, J.O.; Cameron, J.M.; Heck, M.C.; Jancovich, J.K.; Jacobs, B.L. Inhibition of PKR by RNA and DNA viruses. Virus Res. 2006, 119, 100-110.

135. Chen, G.; Ward, B.M.; Yu, E.K.; Chinchar, V.G.; Robert, J. Improved knockout methodology reveals that Frog virus 3 mutants lacking either the $18 \mathrm{~K}$ immediate-early gene or the truncated vIF-2 alpha gene are defective for replication in vivo. J. Virol. 2011, 85, 11131- 1138.

136. Huang, Y.; Huang, X.; Cai, J.; Ye, F.; Guan, L.; Liu, H.; Qin, Q. Construction of green fluorescent protein-tagged recombinant iridovirus to assess viral replication. Virus Res. 2011, 160, 221-229.

137. Xia, L.; Liang, H.; Huang, Y.; Ou-Yang, Z.; Qin, Q. Identification and characterization of Singapore grouper iridovirus (SGIV) ORF162L, an immediate-early gene involved in cell growth control and viral replication. Virus Res. 2010, 147, 30-39.

138.Wang, F.; Bi, X.; Chen, L.M.; Hew, C.L. ORF018R, a highly abundant virion protein from Singapore grouper iridovirus, is involved in serine/threonine phosphorylation and virion assembly. J. Gen. Virol. 2008, 89, 1169-1178.

139.Tran, B.N.; Chen, L.; Liu, Y.; Wu, J.; Velazquez Campoy, A.; Sivaraman, J.; Hew, C.L. A Novel Histone H3 Binding Protein ORF158L from the Singapore Grouper Iridovirus (SGIV). J. Virol. 2011, 85, 9195-9166.

140. Xia, L.; Cao, J.; Huang, X.; Qin, Q. Characterization of Singapore grouper iridovirus (SGIV) ORF086R, a putative homolog of ICP18 involved in cell growth control and virus replication. Arch. Virol. 2009, 154, 1409-1416.

141. Ke, F.; Zhao, Z.; Zhang, Q. Cloning, expression and subcellular distribution of a Rana grylio virus late gene encoding ERV1 homologue. Mol. Biol. Rep. 2009, 36, 1651-1659.

142. Huang, X.; Huang, Y.; Gong, J.; Yan, Y.; Qin, Q. Identification and characterization of a putative lipopolysaccharide-induced TNF-alpha factor (LITAF) homolog from Singapore grouper iridovirus. Biochem. Biophys. Res. Commun. 2008, 373, 140-145.

143.Zhao, Z.; Shi, Y.; Ke, F.; Wei, S.; Gui, J.; Zhang, Q. Constitutive expression of thymidylate synthase from LCDV-C induces a transformed phenoptype in fish cells. Virology 2008, 372, 118-126. 
144. Gray, M. Global Ranavirus Consortium. http://fwf.ag.utk.edu/mgray/ranavirus/Ranavirus.htm (accessed 1 September 2011).

(C) 2011 by the authors; licensee MDPI, Basel, Switzerland. This article is an open access article distributed under the terms and conditions of the Creative Commons Attribution license (http://creativecommons.org/licenses/by/3.0/). 